\title{
DAMPAK SOSIAL PEMBANGUNAN HUTAN TANAMAN INDUSTRI TERHADAP KEHIDUPAN MASYARAKAT DI DUSUN NANAS KECAMATAN SIANTAN KABUPATEN MEMPAWAH
}

\author{
(The Social Impact Of Industrial Plant Forest Development In The Life Of The Community In Dusun \\ Nanas Kecamatan Siantan Mempawah District)
}

\section{Donna Youlla, Ellyta, Hery Medianto K, Dan Saripudin Taligana \\ Program Studi Agribisnis Fakultas Pertanian Universitas Panca Bhakti, Pontianak, Kalimantan Barat, Indonesia}

Email: d_youlla@yahoo.com

Article Submitted : 14-5-2020

Article Accepted : 07-6-2020

\begin{abstract}
This research was conducted with the aim of analyzing the Social Impact of Industrial Plantation Forest Development on Community Life in Dusun Nanas, Siantan District, Mempawah Regency. Especially in the social life of people in dusun nanas as a small village that is located closest to the development of the Industrial Plantation Forest (HTI). The method used in this research is a descriptive method, with an in depth interview approach that is by in-depth interviews of 10 key respondents consisting of RW and RT Chairpersons, Community Leaders, selected residents and several local HTI company employees. The research results obtained are that there are some social impacts that occur in small village after the HTI development can be seen from the assistance and facilities that have been provided by the company to Dusun Nanas community such as public facilities, social facilities, facilities and infrastructure assistance and others where all factors were analyzed descriptively to see the social impact that occurred on the community in Dusun Nanas.
\end{abstract}

Keywords: Impact; social life; industrial forest; community

\section{PENDAHULUAN}

Salah satu pembangunan yang bergerak dalam bidang industri yaitu hutan tanaman industri (HTI) atau hutan tanaman yang dikelola dan diusahakan berdasarkan prinsip pemanfaatan yang optimal, dengan memperhatikan kelestarian lingkungan dan sumber daya alam. Pembangunan (HTI) pertama kali dicanangkan di Indonesia pada tahun 1985 dengan tujuan untuk memenuhi pasokan kayu industri pengolahan bubur kayu (pulp) dan kertas (Kartodihardjo, 2000). Pembangunan dan pengusahaan hutan tanaman harus berdasarkan dengan ketetapan pemerintah PP nomor 7 tahun 1990 tentang Hak Pengusahaan Hutan Tanaman Industri, sehingga pembangunan hutan tanaman ini dapat terlaksana dengan semestinya tanpa ada pihak yang merasa dirugikan.

Lokasi yang menjadi sasaran pembangunan HTI sudah diatur berdasarkan Surat Keputusan Menteri Kehutanan No. 358/ Kpts-II/ 93 tentang tata cara dan persyaratan permohonan hak pengusahaan hutan tanaman industri. Pada pasal 2 dijelaskan bahwa areal hutan yang dapat dialokasikan untuk areal Hak Pengusaha Hutan Tanaman 
Industri(HPHTI adalah kawasan hutan produksi tetap yang tidak produktif dan tidak dibebani hak-hak lain.

Masyarakat Kabupaten Mempawah dimana 90,91 persen penduduknya bekerja di sektor pertanian, yang secara langsung berhubungan dengan hutan dan lahan, sehingga dengan alasan ekonomi juga akan menjadi faktor utama terjadinya perambahan hutan dan lahan (BPS, 2019). Melalui pembangunan ekonomi masyarakat yang terarah maka,hal ini akan dapat menjadi modal dasar dalam upaya pengelolaan hutan dan lahan secara lestari. Upaya tersebut dilakukan hanya semata-mata agar laju pembabatan hutan dapat berimbang dengan laju penanaman atau pelestariannya, karena selama ini laju pembabatan hutan dan penanamannya sama sekali tidak berimbang, sehingga hal ini dapat menimbulkan ketidakseimbangan alam yang ada dan cenderung akan terjadi berbagai kemungkinan bencana alam yang juga akan dirasakan oleh masyarakat itu sendiri. Oleh karena itu, pembangunan hutan tanaman industri di wilayah Kabupaten Mempawah khususnya di Kecamatan Siantan diharapkan dapat meminimalisir adanya penebangan hutan secara liar oleh masyarakat yang berdiam di sekitar hutan.

Salah satu perusahaan di Kabupaten Mempawah yang bergerak di bidang Hutan Tanaman Industri.dan mendapat perijinan dari Menteri Kehutanan adalah PT. Muara Sungai Landak yang berdiri pada tanggal 12 Mei 2012, wilayah konsesinya terdiri dari dua Kecamatan yaitu Kecamatan Siantan, dan Kecamatan Segedong, dengan keputusan IUPHHK-HTI SK Menteri Kehutanan Nomor SK.243/ Menhut-II/ 2012 memiliki luas yaitu \pm 13.000 ha.

Hutan Tanaman Industri (HTI) dibangun untuk meningkatkan potensi dan kualitas hutan produksi dalam pemanfaatan hasil hutan kayu yang dapat dilakukandengan satu atau lebih sistem silvikultur, sesuai dengan karakteristik sumberdayahutan dan lingkungannya (Peraturan Pemerintah No. 3 tahun 2008). Hutan tanaman industri menurut (Arifin, 2001) adalah hutan tanaman yang dibangun dalam rangka meningkatkan potensi dan kualitas hutan produksi dengan menerapkan silvikultur intensif untuk memenuhi kebutuhan bahan baku industri hasil hutan, terutama kayu. Hutan tanaman industri merupakan hutan buatan atau artificial forest/ man-made forest dengan struktur tegakan membentuk hutan seumur.

Menurut Pamulardi (1995) hak pengusahaan hutan tanaman industri adalah hak untuk mengusahakan hutan didalam suatu kawasan huan yangkegiatannya dimulai dari penanaman, pemeliharaan, pengelolaan, dan pemasaran. Setiap pemohon HPHTI sesuai denganKeputusan Menteri Kehutanan Nomor 70/Kpts-II/95 tanggal 6 Februari 1995 wajib menyusun Rencana Tata Ruang (RTR) HTI yang merupakan satu kesatuan dengan penyusunan studi kelayakan.

Pembangunan HTI dalam jangka panjang pasti memilki dampak secara langsung maupun tidak langsung. Dampak kegiatan pembangunan ini muncul karena ada pihak yang diuntungkan dan pihak yang dirugikan, maka penilaian dampak sosial ekonomi juga perlu mengacu kepada mereka yang diuntungkan dan yang dirugikan. Dampak sosial yang sering terjadi dalam pembangunan hutan tanaman industri yaitu adanya sengketa lahan dimana didalam suatu luasan lahan konsesi yang diberikan oleh pengusaha terdapat lahan masyarakat yang tidak terdeteksi sehingga munculnya konflik. Lebih lanjut dikatakan bahwa dampak merupakan sesuatu yang muncul setelah adanya suatu kejadian. Sedangkan pendekatan secara sosiologis dapat diartikan "sebagai penggunaan konsep dasar untuk menelaah sebuah gejala sosial dalam artian dampak sosial merupakan sebuah efek dari fenomena 
p-ISSN 1412-1468 e-ISSN 2355-3545

sosial yang terjadi dalam kehidupan masyarakat" (Soekanto, 2006). Dalam studi dampak sosial, menurut (Soemarwoto, 2005) merupakan suatu perubahan yang terjadi sebagai akibat adanay aktivitas tertentu yang dapat bersifat alamiah, kimia,fisik, maupun biologi. Selanjutnya disebutkan bahwa ada beberapa hal utama yang menjadi indikator perubahan di suatu wilayah antara lain; a). fasilitas pendidikan: tersedianya fasilitas pendidikan untuk masyarakat setempat seperti sekolahan, dan bis sekolah, b). fasilitas beribadat: adanya tempat-tempat ibadah yang disediakan untuk masyarakat setempat, seperti mesjid dan gereja, c). fasilitas kesehatan untuk kepentingan masyarakat di daerah tersebut, seperti puskesmas beserta tenaga medisnya.

Masyarakat menerima masuknya perusahaan untuk melakukan pembangunan HTI di dusun mereka, namun menurut beberapa warga dusun hal ini didorong oleh adanya itikad baik dari sosialisasi yang diberikan perusahaan untuk mensejahterakan masyarakat dalam jangka waktu panjang, salah satunya yang telah nyata diberikan oleh perusahaan adalah pembangunan akses jalan untuk masyarakat dusun sehingga memudahkan masyarakat untuk menjual hasil bumi yang menjadi salah satu mata pencaharian mereka, sehingga pendapatan masyarakat menjadi lebih baik. Dari hasil pengamatan di lapanagn terdapat permasalahan yang tampak nyata dalam penelitian ini yaitu bagaimana dampak sosial yang terjadi di masyarakat di Dusun Nanas Kecamatan Siantan Kabupaten Mempawah setelah adanya pembangunan hutan tanaman industri (HTI) di sana. Adapun tujuan dari penelitian ini adalah untuk mengetahui dampak sosial masyarakat di Dusun Nanas Kecamatan Siantan Kabupaten Mempawah sebagai akibat adanya pembangunan Hutan Tanaman Industri pada PT. Muara Sungai Landak.

\section{METODE PENELITIAN}

Penelitian ini menggunakan metode deskriptif yaitu penelitian dilakukan dengan mengamati sesuatu (objek penelitian) dan kemudian menjelaskan apa yang diamatinya (Morissan, 2012). Selanjutnya ditambahkan pula bahwa metode ini bertujuan untuk menjelaskan suatu kondisi sosial tertentu. Sugiyono (2009) menyebutkan bahwa metode deskriptif adalah penelitian yang dilakukan untuk mengetahui keberadaan variabel mandiri, baik hanya pada satu variabel atau lebih (variabel yang berdiri sendiri) tanpa membuat perbandingan dan mencari hubungan variabel itu dengan variabel yang lain.

Responden yang ditentukan dalam penelitian ini adalah sebanyak 10 responden kunci yang merupakan responden yang berasal dari warga di dusun Nanas Kecamatan Mempawah dan karyawan perusahaan HTI. Responden tersebut terdiri atas 1 orang ketua RW, 1 orang ketua RT, 2 orang tokoh masyarakat dan 3 orang warga biasa serta 3 orang karyawan di perusahaan HTI.

Teknik Skala Likert juga dipergunakan dalam melakukan pengukuran atas jawaban dari pernyataan yang diajukan kepada responden penelitian dengan cara memberikan skor pada setiap item jawaban. Dalam penelitian ini skor untuk setiap jawaban dari pernyataan yang diajukan kepada responden, penelitian ini akan mengacu pada pernyataan (Sugiyono, 2009) Variabel yang akan diukur dijabarkan menjadi indicator variabel. Kemudian indicator tersebut dijadikan sebagai titik tolak untuk menyusun item - item instrument yang dapat berupa pernyataan atau pertanyaan. Untuk keperluan analisis Kuantitatif, maka jawaban itu dapat diberi skor. 
Tabel 1. Skala Likert

\begin{tabular}{clc}
\hline No & \multicolumn{1}{c}{ Kategori } & Nilai \\
\hline 1 & SangatSetuju & 5 \\
2 & Setuju & 4 \\
3 & Ragu Ragu & 3 \\
4 & TidakSetuju & 2 \\
5 & SangatTidakSetuju & 1 \\
\hline
\end{tabular}

Sumber: Sugiyono, (2010)

Hasil persentase digunakan untuk memberikan jawaban atas kelayakan dari aspek-aspek yang diteliti. Kemudian darihasil penyebaran kuesioner tersebut selanjutnya dicari rata-ratanya dengan menggunakan rumus dari Umar (2011), dimana rentang skor dihitung dengan rumus sebagai berikut:

Nilai skor tertinggi $=$ Responden $\mathrm{x}$ Alternatif jawaban tertinggi

Nilai skor terendah $=$ Responden $\mathrm{x}$ Alternatif jawaban terendah

Total range

$=\frac{\text { Nilai skor tertinggi }- \text { Nilai skor terendah }}{\text { Rentang Skor Tertinggi }}$

Berdasarkan data diperoleh rentang skor,
Nilai skor tertinggi $=10 \times 5=50$

Nilai skor terendah $=10 \times 1=10$

Total range $=(50-10) / 5=8$

Rata-rata range $=8 / 10=0.8$

Selanjutnya untuk mengukur skor jawaban respondenatas pertanyaan diperoleh rentang skor dengan cara kontinum ke dalam 5 (lima) kategori/klasifikasi yaitu: Sangat Setuju, Setuju, Ragu-Ragu, Tidak Setuju dan Sangat Tidak Setuju. Skala prestasi kontinum sebagai berikut:

Tabel 2. Kategori Kelayakan

\begin{tabular}{cccc}
\hline No & Skor & Rata-Rata Skor & KategoriKelayakan \\
\hline 1 & $1-10$ & $1-1,8$ & Sangat Tidak Setuju \\
2 & $11-20$ & $1,8-2.6$ & Tidak Setuju \\
3 & $21-30$ & $2,6-3,4$ & Ragu Ragu \\
4 & $31-40$ & $3,4-4,2$ & Setuju \\
5 & $41-50$ & $4,2-5$ & Sangat Setuju \\
\hline
\end{tabular}

Sumber : data olahan, 2020

Data yang dikumpulkan meliputi data primer dan data sekunder. Data primer diperoleh melalui wawancara secara langsung dengan masyarakat dusun yang dengan bantuan daftar pertanyaan (kuesioner) serta melalui pengamatan (observasi) langsung di lapangan. Diantaranya data yang dibutuhkan yakni karakteristik responden (umur dan pendidikan, jumlah anggota keluarga, kepemilikan lahan dll). Data sekunder diperoleh melalui kajian literatur dan sumber data lainnya yang berkaitan dengan masalah 
penelitian seperti Monografi Dusun, baik dari perpustakaan maupun mendatangi instansi terkait.

\section{HASIL PEMBAHASAN}

Responden dalam penelitian ini adalah Ketua RW dan RT, tokoh masyaraka dan warga yang tinggal di sekitar hutan yang mempunyai karakteristik beraneka ragam. Keanekaragaman itu dapat dilihat dari latar belakang kehidupan masyarakat yang sangat mempengaruhi pola pikir masyarakat ketika menerima keberadaan perusahaan. Dari hasil wawancara secara mendalam dengan 10 responden kunci didapat beberapa fakta dampak sosial yang masuk dalam kategori dampak standar (standard impact) yang terjadi di dusun nanas setelah adanya pembangunan hutan tanaman industri, yaitu :

1. Pembangunan infrastruktur jalan dan penerangan/jaringan listrik

Kedua pembangunan ini memberikan banyak manfaat bagi masyarakat setempat, baik dalam hal kelancaran transportasi keluar dusun maupun untuk mendistribusikan hasil pertanian masyarakat. Ini berarti bahwa masyarakat Dusun Nanas sangat memanfaatkan akses jalan, untuk mengangkut hasil pertanian mereka, yang dulunya mereka hanya menggunakan sampan untuk menggangkut hasil pertanian mereka. Sekarang lebih mudah setelah akses jalan ada. Pembangunan infrastruktur jalan oleh perusahaan dimulai dari batas jalan operasional perusahaan hingga ke dalam Dusun Nanas. Jalan yang dibuat oleh perusahaan lebarnya $12 \mathrm{~m}$, jalan tersebut terbuat dari gambut, gambangan (kayu log), tanah merah, batu kerikil, latrit. Kondisi jalan pada saat musim panas sangat kering dan berdebu sedangkan pada musim hujan sebagian jalan becek dan tergenang air. Jalan tersebut dapat dilewati oleh tronton, mobil truk, sepeda motor, dan mobil operasional perusahaan. Perusahaan sangat berkomitmen dalam menyediakan infrastruktur jalan untuk masyarakat dan pembangunan jalan di dusun sudah mencapai $4 \mathrm{~km}$ atau sampai di ujung kampung.

Tabel 3. Tanggapan Responden Terhadap Sarana Infrastruktur Untuk Akses Jalan

\begin{tabular}{lcccc}
\hline \multicolumn{1}{r}{ Tanggapan } & Frekuensi & Bobot & Skor & $\begin{array}{c}\text { Presentase } \\
(\%)\end{array}$ \\
\hline Sangat Tidak Setuju & 0 & 1 & 0 & 0 \\
Tidak Setuju & 0 & 2 & 0 & 0 \\
Ragu-Ragu & 0 & 3 & 0 & 0 \\
Setuju & 5 & 4 & 20 & 50 \\
Sangat Setuju & 5 & 5 & 25 & 50 \\
\hline \multicolumn{1}{c}{ Total } & 10 & & 45 & \\
\hline \multicolumn{1}{c}{ Rata - Rata } & & & 4.5 & 100 \\
\hline
\end{tabular}

Sumber : Data Olahan, 2020

Berdasarkan keterangan pada tabel 3 diatas, skor yang diperoleh yaitu sebesar 4,5. Skor ini termasuk dalam kategori sangat setuju. Ini berarti bahwa masyarakat Dusun Nanas sangat memanfaatkan akses jalan, untuk mengangkut hasil pertanian mereka, yang dulunya mereka hanya menggunakan sampan untuk menggangkut hasil pertanian mereka. Sekarang lebih mudah setelah akses jalan ada. Pembangunan infrastruktur jalan oleh perusahaan dimulai dari batas jalan operasional perusahaan hingga ke dalam 
Dusun Nanas. Jalan yang dibuat oleh perusahaan lebarnya $12 \mathrm{M}$, jalan tersebut terbuat dari gambut, gambangan (kayu log), tanah merah, batu kerikil, latrit. Kondisi jalan pada saat musim panas sangat kering dan berdebu sedangkan pada musim hujan sebagian jalan becek dan tergenang air. Jalan tersebut dapat dilewati oleh tronton, mobil truk, sepeda motor, dan mobil operasional perusahaan. Perusahaan sangat berkomitmen dalam menyediakan infrastruktur jalan untuk masyarakat dan pembangunan jalan di dusun sudah mencapai $4 \mathrm{~km}$ atau sampai di ujung dusun.

Perusahaan juga memberikan bantuan jaringan listrik kepada masyarakat Dusun Nanas, tetapi tidak pada semua warga Dusun Nanas tersebut yang mendapatkan bantuan hanya beberapa warga saja. Perusahaan membantu dengan memberikan bantuan berupa uang tunai kepada warga yang belum mendapatkan jaringan listrik. Sementara warga lainnya sudah mempunyai jaringan listrik dari pemerintah sebelum perusahaan masuk ke pemukiman mereka.

Tabel. 4. Tanggapan Responden Terhadap Bantuan Jaringan Listrik/Penerangan

\begin{tabular}{lcccc}
\hline \multicolumn{1}{c}{ Tanggapan } & Frekuensi & Bobot & Skor & Presentase (\%) \\
\hline Sangat Tidak Setuju & 0 & 1 & 0 & 0 \\
Tidak Setuju & 0 & 2 & 0 & 0 \\
Ragu-Ragu & 1 & 3 & 3 & 10 \\
Setuju & 9 & 4 & 36 & 90 \\
Sangat Setuju & 0 & 5 & & 0 \\
\hline \multicolumn{1}{c}{ Total } & 10 & & 39 & 100 \\
\hline \multicolumn{1}{c}{ Rata - Rata } & & 3.9 &
\end{tabular}

Berdasarkan tabel 4, jumlah skor yang diperoleh yaitu sebesar 3,9 yang mana ini berarti masuk dalam kategori setuju. Fasilitas berupa jaringan listrik sangat membantu masyarakat untuk beraktifitas, sehingga hampir semua setuju bahwa fasilitas ini sangat bermanfaat. Lebih lanjut didapatkan informasi dari wawancara bahwa perusahaan memberikan bantuan jaringan listrik kepada masyarakat Dusun Nanas ini tidak pada semua masyarakat Dusun Nanas dari 101 KK yang mendapatkan bantuan tersebut, hanya beberapa masyarakat yang mendapatkan bantuan jaringan listrik dari Perusahaan. Perusahaan membantu dengan memberikan bantuan berupa uang tunai kepada masyarakat yang belum mendapatkan jaringan listrik. Sementara masyarakat lainnya sudah mempunyai jaringan listrik dari pemerintah sebelum perusahaan masuk ke pemukiman mereka.

Kedepannya warga Dusun Nanas berharap kepada perusahaan agar bisa memberikan bantuan penerangan khususnya penerangan untuk jalan menuju ke Dusun, karena kondisi jalan tersebut belum ada penerangannya seperti lampu jalan. Warga Dusun mengharapkan kepada perusahaan agar kedepannya bantuanbantuan fasilitas sosial dapat lebih dimaksimalkan lagi.

2. Ketersediaan fasilitas pendidikan dasar sangat penting sebagai modal dasar masyarakat untuk memperbaiki pola pendidikan dan peningkatan taraf hidup masyarakat.

Halimah, (2010) menyatakan bahwa keinginan masyarakat untuk mengenyam 
pendidikan harus didukung dengan sarana dan prasarana pendidikan yang baik. Dalam hal ini bantuan yang diberikan oleh perusahaan untuk fasilitas pendidikan sudah ada walaupun masih sangat terbatas yaitu beasiswa yang berupa uang tunai dan buku pelajaran kepada murid yang berprestasi antara lain untuk peringkat 1 , dan 2 sebesar Rp 300.000 perorang, sehingga total beasiswa yang diberikan oleh perusahaan untuk setiap kelas sebesar Rp 600.000,- . Namun bantuan ini sifatnya menunggu dimana ketika ada warga yang meminta bantuan dan telah disertai dengan bukti-bukti prestasi yang mendukung barulah dana beasiswa dapat dikeluarkan. Selanjutnya perusahaan juga memberikan bantuan untuk pembangunan Sekolah Dasar dalam bentuk material untuk penambahan bahan bangunan atau perbaikan gedung sekolah di Dusun Nanas. Dari tabel 5 di bawah ini dapat dilihat bahwa semua responden setuju dengan bantuan keuangan yang diberikan oleh Perusahaan untuk melanjutkan pendidikan.

Tabel 5. Tanggapan Responden Terhadap Bantuan Keuangan Untuk Lanjutan Pendidikan

\begin{tabular}{lcccc}
\hline \multicolumn{1}{c}{ Tanggapan } & Frekuensi & Bobot & Skor & Presentase $(\%)$ \\
\hline Sangat Tidak & 0 & & 0 & 0 \\
Setuju & 0 & 1 & 0 & 0 \\
Tidak Setuju & 0 & 3 & 0 & 0 \\
Ragu-Ragu & 10 & 4 & 40 & 100 \\
Setuju & 0 & 5 & 0 & 0 \\
Sangat Setuju & 10 & & 40 & 100 \\
\hline \multicolumn{1}{c}{ Total } & & 4.0 & \\
\hline
\end{tabular}

Sumber : Data Olahan 2020

3. Bantuan pembangunan untuk kegiatan beribadah seperti mushola dan vihara.

Sarana dan prasarana untuk ibadah sangat diperlukan oleh masyarakat Dusun Nanas, sehingga oleh perusahaan pembangunan dua tempat peribadatan ini menjadi prioritas. Diakui perusahaan telah memberikan bantuan berupa uang tunai dan bahan- bahan material lainnya yang diperlukan untuk pembangunan mushola dan vihara untuk masyarakat Dusun Nanas. Pembangunan tempat beribadah saat ini sudah terealisasi dan sudah dapat dimanfaatkan oleh masyarakat Dusun Nanas dimana sebagian besar masyarakat Dusun Nanas memeluk agama Islam dan Budha. Pembangunan tempat ibadah di dusun mereka memberikan manfaat yang cukup besar bagi masyarakat Dusun Nanas.

Dari tabel 6 dapat dilihat bahwa hampir semua responden menyetujui pembangunan tempat ibadah di dusun mereka. Berdasarkan jumlah skor yang diperoleh yaitu sebesar 4,1 Skor ini termasuk dalam kategori Sangat Setuju. Perusahaan memberikan bantuan berupa uang tunai \pm 68 juta dan bahan- bahan material lainnya yang diperlukan untuk pembangunan Mesjid dan Vihara untuk masyarakat Dusun Nanas. Pembangunan tempat beribadah saat ini sudah terealisasi dan sudah dapat dimanfaatkan oleh masyarakat Dusun Nanas untuk beribadah, 
Tabel 6. Tanggapan Responden Terhadap Pembangunan Tempat Ibadah

\begin{tabular}{lcccc}
\hline \multicolumn{1}{c}{ Tanggapan } & Frekuensi & Bobot & Skor & Presentase (\%) \\
\hline Sangat Tidak Setuju & & 1 & 0 & \\
Tidak Setuju & 0 & 2 & 0 & 0 \\
Ragu-Ragu & 0 & 3 & 0 & 0 \\
Setuju & 9 & 4 & 36 & 90 \\
Sangat Setuju & 1 & 5 & 5 & 10 \\
\hline \multicolumn{1}{c}{ Total } & 10 & & 41 & 100 \\
\hline \multicolumn{1}{c}{ Rata - Rata Skor } & & & 4,1 &
\end{tabular}

\section{Sumber : Data Olahan 2020}

4. Pelayanan kesehatan

Pelayanan kesehatan adalah upaya yang dilakukan oleh suatu organisasi baik secara sendiri atau bersama-sama untuk memelihara dan meningkatkan kesehatan, mencegah dan menyembuhkan penyakit serta memulihkan perseorangan, kelompok dan ataupun masyarakat (Azwar, 1994).

Keterangan dari sebagian masyarakat perusahaan belum ada memberikan bantuan pengobatan, seperti menyediakan klinik ataupun tim medis untuk masyarakat, masyarakat menyatakan bahwa dari berdirinya perusahaan sampai saat ini belum ada program untuk bantuan kesehatan kepada masyarakat. Pihak perusahaan hanya diberikan bantuan berupa uang tunai untuk biaya berobat jika ada masyarakat yang sakit. Masyarakat Dusun Nanas berharap kepada perusahaan untuk bisa menyediakan fasilitas kesehatan, adanya perawat ataupun Mantri dari perusahaan, sehingga mempermudah masyarakat untuk berobat jika suatu saat ada warga yang terserang penyakit. Serta bisa memberikan bantuan pengobatan secara gratis untuk warga. Tujuan pelayanan kesehatan adalah untuk meningkatkan derajat kesehatan dan kemampuan masyarakat secara menyeluruh dalam memelihara kesehantannya untuk mencapai kesehatan yang optimal mandiri, keluarga dan masyarakat (Suratman dkk, 2014).

Tabel 7. Tanggapan Responden Terhadap Bantuan Fasilitas Kesehatan

\begin{tabular}{lcccc}
\hline \multicolumn{1}{c}{ Tanggapan } & Frekuensi & Bobot & Skor & Presentase (\%) \\
\hline Sangat Tidak Setuju & 0 & 1 & 0 & 0 \\
Tidak Setuju & 0 & 2 & 0 & 0 \\
Ragu-Ragu & 7 & 3 & 21 & 70 \\
Setuju & 3 & 4 & 12 & 30 \\
Sangat Setuju & 0 & 5 & 0 & \\
\hline \multicolumn{1}{c}{ Total } & 10 & & 33 & 100 \\
\hline \multicolumn{1}{c}{ Rata - Rata Skor } & & & 3,3 &
\end{tabular}

Sumber : Data Olahan 2020 
Berdasarkan keterangan pada tabel 7, jumlah skor yang diperoleh yaitu sebesar 3,3. Skor ini termasuk dalam kategori ragu - ragu. Keterangan dari responden menyatakan perusahaan belum ada memberikan bantuan pengobatan, seperti menyediakan klinik ataupun tim medis untuk masyarakat, responden juga menyatakan bahwa dari sejak berdirinya perusahaan sampai saat ini belum ada program untuk bantuan kesehatan kepada masyarakat.

5.Fasilitas olahraga

Fasilitas olahraga seperti lapangan badminton untuk masyarakat di Dusun Nanas, telah diberikan oleh perusahaan beberapa tahun lalu. Perusahaan juga memberikan sarana perlengkapan olahraga khususnya badminton untuk melengkapi fasilitas yang ada, di antaranya bola, jaring net, dan tiang net.

Tabel 8.Tanggapan Responden Terhadap Bantuan Fasilitas Olahraga

\begin{tabular}{lcccc}
\hline \multicolumn{1}{c}{ Tanggapan } & Frekuensi & Bobot & Skor & Presentase $(\%)$ \\
\hline Sangat Tidak Setuju & 0 & 1 & 0 & 0 \\
Tidak Setuju & 0 & 2 & 0 & 0 \\
Ragu-Ragu & 0 & 3 & 0 & 0 \\
Setuju & 8 & 4 & 32 & 80 \\
Sangat Setuju & 2 & 5 & 10 & 20 \\
\hline \multicolumn{1}{c}{ Total } & 10 & & 42 & \\
\hline \multicolumn{1}{c}{ Rata - Rata } & & & 4,2 & 100 \\
\hline
\end{tabular}

Sumber : data olahan (2020)

Berdasarkan tabel 8, jumlah skor yang diperoleh yaitu sebesar 4,2. Skor ini termasuk dalam kategori setuju. Sarana dan prasarana olahraga untuk masyarakat dan karyawan sangat diperlukan selain sebagai tempat berolahraga, masyarakat dan karyawan juga dapat memanfaatkannya sebagai sarana hiburan dari aktifitas kerja sehari-hari. Sehingga sebagian besar responden sangat mendukung dengan bantuan yang diberikan ini. Bantuan ini merupakan wujud komitmen perusahaan dalam bidang olahraga. Sarana dan prasarana olahraga untuk masyarakat dan karyawan sangat diperlukan selain sebagai tempat berolahraga, masyarakat dan karyawan juga dapat memanfaatkannya sebagai sarana hiburan dari aktifitas kerja sehari-hari. Warga dusun nanas juga memperoleh bantuan dari perusahaan berupa perlengkapan olahraga lainnya yaitu bola dan kostum team. Bantuan ini merupakan permintaan dari masyarakat, karena di dusun masih banyak anak muda yang menyukai olahraga sepak bola.

Selanjutnya dari wawancara yang dilakukan didapatkan dua masalah utama yang diketahui bersifat negatif yang dirasakan oleh masyarakat Dusun Nanas yaitu :

\section{Lingkungan}

Sejak masuknya perusahaan HTI. Yaitu berdampak pada lingkungan terutama pada sektor pertanian. Beberapa responden menyatakan bahwa jika musim hujan tiba air sungai dari aliran perusahaan meluap kepemukiman masyarakat Dusun Nanas sehingga menyebabkan banjir, hal tersebut berdampak pada tanaman yang sedang diusahakan warga di Dusun Nanas. Ke depannya warga dusun nanas sangat berharap akan adanya solusi atau pemecahan dari permasalahan ini. Didapatkan sejumlah data dan informasi bahwa awalnya sebelum adanya pembangunan perusahaan HTI di dusun nanas, 
p-ISSN 1412-1468 e-ISSN 2355-3545

warga setempat banyak mengusahakan komoditas pertanian dimana hasil yang didapat juga sangat bermanfaat bagi kehidupan mereka. Komoditas yang diusahakan antara lain : padi, keladi, jagung, nanas dan kedelai. Kini hanya tanaman padi saja yang masih dapat diusahakan oleh masyarakat sedangkan tanaman lain sudah tidak bisa dikarenakan lahan mereka selalu tergenang.

2.Peluang kerja

Dampak negatif yang dirasakan masyarakat Dusun Nanas yaitu dari segi peluang kerja, karena sebagian masyarakat lokal yang bekerja pada perusahaan HTI hanya sebagai karyawan buruh harian, dan borongan. Sementara untuk bagian posisi staf dan pengawas lapangan diisi oleh masyarakat yang berasal dari luar. Sehingga menimbulkan kecemburuan sosial kepada masyarakat Dusun Nanas.

\section{KESIMPULAN}

1. Dari hasil analisis seluruh variabel pengamatan dapat dilihat bahwa masyarakat Dusun Nanas telah menerima dengan baik dampak dari pembangunan hutan tanaman industri di wilayah mereka. Hal ini ditunjukan dengan adanya bantuan yang diberikan oleh masyarakat dari perusahaan.

2. Kondisi perkembangan sosial ekonomi masyarakat di Dusun Nanas setelah perusahan HTI masuk secara umum sudah mengalami kemajuan hal ini dapat dilihat dari respon yang diperlihatkan oleh masyarakat terhadap keberadaan perusahaan HTI yang ada di lingkungan mereka.

\section{DAFTAR PUSTAKA}

Arief, Arifin. 2001. Hutan dan Kehutanan. Penerbit Kanisius. Yogyakarta.

Arsyad, Lincolin. et, all. 2011. Strategi Pembangunan Perdesaan Berbasis Lokal .Cetakan Pertama. Penerbit UPP STIM YKPN. Yogyakarta.
Azwar, Azrul (1994), Program Menjaga Mutu Pelayanan Kesehatan Aplikasi Prinsip Lingkaran Pemecahan Masala, Yayasan Penerbitan Ikatan Dokter Indonesia, Jakarta

Fitriani 2014 Analisis Dampak Pembangunan Hutan Tanaman Industri (HTI) Terhadap Sosial Ekonomi Masyarakat Di Dusun Belangiran Kabupaten Landak. Skripsi

Halimah, Siti. 2010. Faktor-Faktor yang Mempengaruhi Perilaku Aman Karyawan di PT SIM Plant Tambun II Tahun 2010. Skripsi. Jakarta: UIN.

Husein, Umar. 2011. Metode Penelitian Untuk Skripsi dan Tesis Bisnis Edisi 11, PT Raja GrafindoPersada, Jakarta

Morissan. 2012, Metode Penelitian Survei, Prenamedia Group, Jakarta

Peraturan Menteri Kehutanan Nomor : P.18/Menhut-II/2004.

Peraturan Pemerintah No. 3 Tahun 2008 Tentang Tata Hutan dan Penyusunan Rencana Pengelolaan Hutan, Serta Pemanfaatan Hutan. Jakarta

Pamulardi. 1995. Kehutanan dan Pembangunan Bidang Kehutanan, Raja GrafindoPersada, Jakarta.

Soekanto, S. 2006, Sosiologi Suatu Pengantar, Rajawali Pers, Jakarta.

Soemarwoto, Ott. 2005. Analisis Mengenai Dampak Lingkungan, Gadjahmada University Press, Yogyakarta.

Sugiyono, 2009, Metode Penelitian Kuantitatif, Kualitatif dan $R \& D$, Alfabeta, Bandung. 
Suhendang. 2002. Pengantar Ilmu Kehutanan. Yayasan Penerbit Fakultas Kehutanan, Institut Pertanian Bogor, Bogor.

Suratman, Ratih, Saleh, H. 2014, Ilmu Sosial Budaya Dasar, Intimedia, Malang
Suratmo, F. Gunawan. 1998, Analisis Mengenai Dampak Lingkungan, Gajahmada University Press, Yogyakarta. 